\title{
Degradation and sorption of fipronil and atrazine in Latossols with organic residues from sugarcane crop
}

\author{
Degradação e sorção de fipronil e atrazina em Latossolos com \\ resíduos orgânicos da cultura de cana-de-açúcar
}

\author{
Raquel de Oliveira Silva ${ }^{I}$ Rômulo Penna Scorza Júnior ${ }^{I I}$ Maricy Raquel Lindenbah BonfáiII \\ Maria Fernanda Zaneli Campanari ${ }^{\mathrm{III}}$ Ieda de Carvalho Mendes $^{\mathrm{IV}}$
}

\section{ABSTRACT}

Organic residues from sugarcane crop and processing (vinasse, boiler ash, cake filter, and straw) are commonly applied or left on the soil to enhance its fertility. However, they can influence pesticide degradation and sorption. The objective of this study was to assess the effect of adding these organic residues on the degradation and sorption of fipronil and atrazine in two soils of the State of Mato Grosso do Sul, MS, Brazil. The degradation experiment was carried out with laboratory-incubated (40 days; $28^{\circ} \mathrm{C} ; 70 \%$ field capacity) soils $(0-10 \mathrm{~cm})$. The batch equilibration method was used to determine sorption. Fipronil (half-life values of 15-105 days) showed to be more persistent than atrazine (717 days). Vinasse application to the soil favored fipronil and atrazine degradation, whereas cake filter application decreased the degradation rates for both pesticides. Values for sorption coefficients $(K d)$ were determined for fipronil $\left(5.1-13.2 \mathrm{~mL} \mathrm{~g}^{-1}\right)$ and atrazine $\left(0.5-1.5 \mathrm{~mL} \mathrm{~g}^{-1}\right)$. Only straw and cake filter residues enhanced fipronil sorption when added to the soil, whereas all sugarcane residues increased atrazine sorption.

Key words: organic residue, degradation and sorption.

\section{RESUMO}

Resíduos orgânicos do cultivo e processamento da cana-de-açúcar (vinhaça, cinzas, torta de filtro e palha) são usualmente aplicados ou deixados no solo para aumentar sua fertilidade, mas eles podem influenciar na degradação e sorção de agrotóxicos. O objetivo deste estudo foi avaliar o efeito da adição desses resíduos orgânicos no solo sobre a degradação e sorção do fipronil e da atrazina em dois solos no Estado de Mato Grosso do Sul, MS, Brasil. O experimento de degradação foi realizado com solos $(0-10 \mathrm{~cm})$ incubados em laboratório $\left(40\right.$ dias; $28^{\circ} \mathrm{C}$; $70 \%$ da capacidade de campo). Para determinar a sorção, foi usado o método da batelada. Fipronil mostrou ser mais persistente (valores de meia-vida entre 15-105 dias) que atrazina (7-17 dias). O solo com adição de vinhaça favoreceu a degradação de fipronil e atrazina, enquanto adição da torta de filtro desacelerou o processo. Os valores do coeficiente de sorção (Kd) foram determinados para fipronil $\left(5,1-13,2 \mathrm{~mL} \mathrm{~g}^{-1}\right)$ e atrazina $\left(0,5-1,5 \mathrm{~mL} \mathrm{~g}^{-1}\right)$. Apenas os resíduos palha e torta de filtro aumentaram a sorção de fipronil quando adicionados ao solo, enquanto todos os resíduos aumentaram a sorção de atrazina.

Palavras-chave: resíduo orgânico, degradação e sorção.

\section{INTRODUCTION}

The sugarcane planted area in the State of Mato Grosso do Sul, MS, Brazil had a 143\% expansion (275-668 thousand ha) in the period 20082014 (CONAB, 2014). As a consequence, an increase was observed in the total consumption of pesticides for this crop as well as in the amount of plantgenerated by-products or residues such as bagasse, filter cake, vinasse, and boiler ash, which are usually disposed on the ground.

These residues have high levels of organic material and nutrients, being used as fertilizers. However, addition of these residues to the soil can alter its physicochemical and microbiological properties and thus influence the environmental behavior of pesticides, mainly in the degradation and sorption processes (VASCONCELOS et al., 2010; JIANG et al., 2012).

\footnotetext{
'Programa de Pós-graduação em Recursos Naturais, Universidade Estadual de Mato Grosso do Sul (UEMS), Dourados, MS, Brasil IIEmbrapa Agropecuária Oeste, 79804-970, Dourados, MS, Brasil. E-mail: romulo.scorza@embrapa.br. Corresponding author.

IIIUniversidade Federal da Grande Dourados (UFGD), Dourados, MS, Brasil.

${ }^{\mathrm{IV}}$ Embrapa Cerrados, Planaltina, DF, Brasil. 
The insecticide fipronil and the herbicide atrazine are used in the soil preparation and planting stages of sugarcane crops and are applied directly to the soil. Thus, agricultural practices, such as adding organic residues or by-products to the soil, which influence the physical, chemical, and biological characteristics of the soil and; therefore, pesticide-soil interactions should be better studied. GIORI et al. (2014a) observed that addition of boiler ash to soils with sugarcane crop in the State of São Paulo, SP, Brazil caused an increase in the sorption of alachlor (4-fold) and diuron (10-fold). In SP State, straw was also left on the ground after harvest of sugarcane and average increases were observed by GIORI et al. (2014b) in the sorption of alachlor (1.6-fold) and diuron (2.3-fold) and by PEREIRA-JUNIOR et al. (2015) in the sorption of hexazinone (1.8-fold) and tebuthiuron (1.9-fold). Thus, most studies, which aimed to evaluate the influence of adding sugarcane residues to the soil on the pesticide-soil interaction, were conducted in SP State. Similar reports for the conditions and types of soil in the MS State, are unknown. The objective of the present study was to evaluate the influence of the organic residues filter cake, straw, boiler ash and vinasse on the degradation and sorption of fipronil and atrazine in two representative soils with sugarcane crops in MS State.

\section{MATERIALS AND METHODS}

Soil samples were collected in the experimental field of Embrapa Agropecuária Oeste, in Dourados (22 ${ }^{\circ} 16^{\prime} 29^{\prime \prime} \mathrm{S}$ and $\left.54^{\circ} 48^{\prime} 51^{\prime \prime} \mathrm{W}\right)$, where the soil is classified as DystroferricRed Latosol (LVdf; typical of clay texture), and Ponta Porã (22 $33^{\circ} 06^{\prime \prime}$ $\mathrm{S}$ and 53.38'37" W), where the soil is classified as Dystrophic Red Latossol (LVd; typical of medium texture) (SANTOS et al., 2006). The soils were left fallow over the past two years. Soil subsamples were collected randomly with a Dutch auger (depth:
$0-10 \mathrm{~cm})$, and were then mixed and homogenized to form composite samples (mass: $c a$. $5 \mathrm{~kg}$ ) from each soil. Samples were air dried under shade, crushed in a mill, and sieved (mesh: $2 \mathrm{~mm}$ ). Chemical and physical properties of the LVdf and LVd soils were respectively determined for organic matter (33.4 and $\left.17.5 \mathrm{~g} \mathrm{~kg}^{-1}\right)$, sand (245 and $743 \mathrm{~g} \mathrm{~kg}^{-1}$ ), clay (630 and $\left.213 \mathrm{~g} \mathrm{~kg}^{-1}\right)$, and $\mathrm{pH}\left(\mathrm{CaCl}_{2} ; 4.8\right.$ and 4.9$)$.

The production residues (filter cake, $\mathrm{FC}$; boiler ash, AS; and vinasse, VI) were collected in a production plant, and the agricultural residue (straw, SR) was collected in a crop area, both in the city of Dourados, MS State. After the FCs were collected, they were shade dried and sieved, whereas SR was cut into 2-mm pieces. As for AS and VI, they were used untreated. The chemical characteristics of the residues (Table 1) were determined according to PIATV (2014) and ALCARDE (2009). Dosage of residue in the soil required to perform the degradation and sorption experiments was calculated according to both the amount used in the field by the local production plants and density of each soil (FC: 35ton ha ${ }^{-1}$; SR: 18ton ha ${ }^{-1}$; AS: 10t ha ${ }^{-1}$; and VI: $\left.150 \mathrm{~m}^{3} \mathrm{ha}^{-1}\right)$. A corresponding amount of each residue was added to the soil samples $(1 \mathrm{~kg})$ in plastic trays. Both components were then mixed until complete homogenization and left in a BOD-type incubator $\left(28^{\circ} \mathrm{C} ; 23\right.$ days). Moisture was maintained at $70 \%$ of field capacity (FC) with periodic addition of ultrapure water. The 23-day period after the residues were added, was required for stabilization of the soil microbial activity (OECD 302, 2002).

In the degradation experiments, the soil samples $(10 \mathrm{~g})$ together with the residues were weighed and conditioned in beakers (capacity: $100 \mathrm{~mL}$ ). Aliquots of the fipronil and atrazine working solution were added to the soil mixture in each beaker to obtain a final concentration of the pesticide equal to $5 \mu \mathrm{g}$ per $\mathrm{g}$ of soil. After the samples were fortified, they were homogenized and immediately adjusted for moisture content $(70 \%$ of FC) with ultrapurewater.

Table 1 - Chemical characteristics of the residues filter cake, straw, boiler ash, and vinasse.

\begin{tabular}{lcccccccccc}
\hline Residues & $\mathrm{pH}\left(\mathrm{CaCl}_{2}\right)$ & $\mathrm{K}$ & $\mathrm{P}$ & $\mathrm{Ca}$ & $\mathrm{Mg}$ & $\mathrm{S}$ & $\mathrm{Fe}$ & $\mathrm{C}$ & $\mathrm{N}$ & $\mathrm{CEC} \mathrm{mmol} \mathrm{kg}^{-1}$ \\
\hline Filter cake & 4.7 & $6.3^{*}$ & 0.3 & 1.4 & 0.7 & 0.7 & 2.4 & 335 & 2.4 \\
Straw & 5.7 & 2.0 & 0.5 & 2.5 & 0.9 & - & 10.4 & 378 & 5.9 & 19 \\
Boiler ash & 8.3 & 9.0 & 2.6 & 5.8 & 3.2 & - & 32.3 & 43 & 0.1 & 29 \\
Vinasse & 4.3 & 1.3 & 0.03 & 0.3 & 0.1 & 0.2 & 0.04 & 8 & 0.2 & - \\
\hline
\end{tabular}

${ }^{*}$ The values for $\mathrm{K}, \mathrm{P}, \mathrm{Ca}, \mathrm{Mg}, \mathrm{S}, \mathrm{Fe}, \mathrm{C}$, and $\mathrm{N}$ are expressed in $\mathrm{g} \mathrm{kg}^{-1}$ for filter cake, straw, and boiler ash, and in $\mathrm{g} \mathrm{L}^{-1}$ for vinasse. $\mathrm{CEC}=$ cation exchange capacity. 
Each beaker was covered with an aluminum foil cap perforated with six holes to maintain the aerobic condition inside the beaker. The samples were incubated in BOD-type incubator $\left(28^{\circ} \mathrm{C}\right.$, in the dark). Soil moisture was kept constant by weighing daily the soil samples and adding ultrapure water to replace the losses. Experiments were conducted (40 days) with three repetitions per treatment, and samples were taken at $0,7,14,20,27,34$, and 40 days after fortification. In addition to the treatments with organic residues, a control $(\mathrm{CO})$ treatment (with no addition of residue) and another with sterile (ST) soil were also used. The fipronil and atrazine residues were extracted from the soil samples $(10 \mathrm{~g})$ with methanol $(40 \mathrm{~mL})$ and the extracts were conditioned in an Erlenmeyer flask (capacity: $50 \mathrm{~mL}$ ) with cap, which was placed on a shaking table $\left(216 \mathrm{rpm} ; 25^{\circ} \mathrm{C} ; 1 \mathrm{~h}\right)$. After decantation $(1 \mathrm{~h})$, aliquots $(10 \mathrm{~mL})$ were taken, centrifuged $\left(15^{\circ} \mathrm{C}, 15 \mathrm{~min} ; 4000 \mathrm{rpm}\right)$, filtered on regenerated cellulose filter (pore diameter: $0.45 \mu \mathrm{m}$ ), and stored in a freezer $\left(-20^{\circ} \mathrm{C}\right)$ until analysis by high-performance liquid chromatography (HPLC). Variable recovery of atrazine was obtained for LVdf (79-87\%) and LVd (77-93\%) soils, and fipronil for LVdf (81-99\%) and LVd (72-92\%) soils.

The batch method was used in the sorption experiments (OECD 106, 2000). Soil samples (10 and $5 \mathrm{~g}$ ) mixed with the residue for the pesticides atrazine orfipronil, respectively, were weighed separately, and $\mathrm{CaCl}_{2}\left(10 \mathrm{~mL}, 0.01 \mathrm{~mol} \mathrm{~L}^{-1}\right)$ aqueous solution was added to each flask. The samples were left on a shaking table $\left(216 \mathrm{rpm} ; 25^{\circ} \mathrm{C} ; 12 \mathrm{~h}\right)$ for preequilibration. Subsequently, a fortified pesticide solution $(40 \mathrm{~mL})$ was added to each flask. Mixture remained under stirring (24h) and then it was allowed to stand for decantation (2h). Part of the liquid fraction $(10 \mathrm{~mL})$ was removed and centrifuged $\left(15^{\circ} \mathrm{C}\right.$, 20min; 4000rpm). All samples were filtered through a regenerated cellulose filter (pore diameter: $0.45 \mu \mathrm{m}$ ).

For identification and quantitative determination of fipronil and atrazine, a highperformance liquid chromatography HPLC (Varian, model 920-LC) operating with a diode array detector (DAD; $\mu=220 \mathrm{~nm})$ was used. The compounds in the samples $(20 \mu \mathrm{L})$ were quantified by comparing the areas of the chromatogram peaks with the corresponding area in the calibration curve, which was constructed with analyses of the individual analytical standards. The analytes were separated using a Polaris reversed-phase $\left(\mathrm{C}_{18}\right)$ column $(25 \mathrm{~cm} \mathrm{x}$ $4.6 \mathrm{~mm} \times 5 \mu \mathrm{m})$ and guard column $(2.5 \mathrm{~cm} \times 4.6 \mathrm{~mm} \times$ $5 \mu \mathrm{m})$, which was maintained in an oven $\left(40^{\circ} \mathrm{C}\right)$, and eluted with an isocratic solvent system (flow rate: $\left.1 \mathrm{~mL} \min ^{-1}\right)$ containing methanol $(60 \%)$, ultrapure water $(30 \%)$ and acetonitrile $(10 \%),(\mathrm{v} / \mathrm{v} / \mathrm{v})$. Under these conditions (analysis time: $20 \mathrm{~min}$ ), the retention times were 6.43 (atrazine), and 12.88min (fipronil).

For each treatment, the amounts of pesticides remaining in the soil 20 days after application of atrazine and 40 days after application of fipronil, as well as the values for sorption coefficients $(\mathrm{Kd})$ underwent analysis of variance. Mean values were compared by the Tukey's test (5\%) using the $R$ program (R DEVELOPMENT CORE TEAM, 2012). Then, the first-order kinetics (FOK) model was fit to the remaining quantities for each treatment as a function of time. For this purpose, the SigmaPlot ${ }^{\circledR}$ (12.5) program was used to fit the equation to the experimental data through nonlinear regression by the least squares method. The FOK model is given by the equation: $\mathrm{C}=\mathrm{C}_{0} \cdot \mathrm{e}^{-k t}$, where $\mathrm{C}$ is the amount of the pesticide remaining in the soil $(\%$ of the applied dose), $\mathrm{C}_{0}$ is the initial amount applied (\%), $k$ is a degradation rate constant $\left(\right.$ day $\left.^{-1}\right)$, and $t$ is the time (days). The values for half-life $\left(\mathrm{DT}_{50}\right)$ of fipronil and atrazine under the different conditions were estimated using the following relationship: $\mathrm{DT}_{50}=\frac{0.693}{\mathrm{k}}$.

\section{RESULTS AND DISCUSSION}

A significant interaction $(\mathrm{P}<0.05)$ was observed between the different types of organic residues and soils evaluated. In both soils, the highest remaining amounts of fipronil were reported in the soil treated with FC and in the ST soil (Table 2). However, significant difference was not observed between

Table 2 - Amounts of pesticide ( $\mu \mathrm{g} \mathrm{g}^{-1}$ ) remaining 20 (atrazine) and 40 days (fipronil) after its application to the soil.

\begin{tabular}{lcccc}
\hline \multirow{2}{*}{ Treatments } & \multicolumn{3}{c}{----Fipronil $\left(\mu \mathrm{g} \mathrm{g}^{-1}\right)$---- } & \multicolumn{3}{c}{----Atrazine $\left(\mu \mathrm{g} \mathrm{g}^{-1}\right)$----- } \\
& LVdf & \multicolumn{1}{c}{ LVd } & \multicolumn{1}{c}{ LVdf } & \multicolumn{1}{c}{ LVd } \\
\hline Sterile soil & $3.41 \mathrm{aA}$ & $3.68 \mathrm{aA}$ & $2.02 \mathrm{aA}$ & $1.96 \mathrm{aA}$ \\
Filter cake & $3.07 \mathrm{aA}$ & $3.40 \mathrm{aA}$ & $2.13 \mathrm{aA}$ & $2.06 \mathrm{aA}$ \\
Boiler ash & $1.38 \mathrm{bA}$ & $1.70 \mathrm{bcA}$ & $1.32 \mathrm{bA}$ & $0.43 \mathrm{cB}$ \\
Straw & $1.29 \mathrm{bcB}$ & $2.28 \mathrm{bA}$ & $0.42 \mathrm{cB}$ & $1.18 \mathrm{bA}$ \\
Control & $1.11 \mathrm{bcB}$ & $2.01 \mathrm{bcA}$ & $1.60 \mathrm{ab} \mathrm{A}$ & $0.64 \mathrm{bcB}$ \\
Vinasse & $0.71 \mathrm{cB}$ & $1.57 \mathrm{cA}$ & $0.54 \mathrm{cA}$ & $0.24 \mathrm{cA}$ \\
\hline
\end{tabular}

$\mathrm{CV}$ fipronil $=11.8 \%$ and $\mathrm{CV}$ atrazine $=19.6 \%$. Mean values followed by the same letter (lower case in the column and upper case in the row) for each individual pesticide are not significantly different by the Tukey's test $(5 \%)$. LVdf $=$ Distroferric Red Latossol (typical of clay texture); LVd = Dystrophic Red Latossol (typical of medium texture). 
them $(\mathrm{P}>0.05)$. This indicates that degradation of fipronil was slower in both soils and in the ST soil after the FC was added. The lowest amount of remaining fipronil was found in the soils treated with VI, indicating that this residue accelerated fipronil degradation. Significant difference was not observed between the $\mathrm{CO}$ treatments and in soils treated with SR and AS, indicating that addition of these residues neither accelerates nor deaccelerates fipronil degradation. Regarding fipronil in both soil types, a significant difference $(\mathrm{P}<0.05)$ was observed between $\mathrm{CO}$ treatments and soils treated with $\mathrm{SR}$ and VI. However, a greater amount of fipronil remained in the LVd soil, indicating a slower degradation of this pesticide in this soil treated with these residues (Table 2). Significant difference was not observed $(\mathrm{P}>0.05)$ for $\mathrm{ST}$ soil and soils treated with FC and $\mathrm{AS}$, in relation to soil types. The highest values for atrazine were found to remain in the ST soil and soils treated with FC, indicating a slower degradation for these conditions in both soils (Table 2). The lowest values for atrazine remaining in the LVdf soil were observed in the treatments with SR and VI, indicating that addition of these residues accelerates atrazine degradation. Significant difference was not observed $(\mathrm{P}>0.05)$ between the $\mathrm{CO}$ treatments and the LVdf soil treated with AS, i.e, these conditions do not interfere with the degradation process. The lowest values of remaining amounts and therefore, faster degradation of pesticide in the LVd soil was observed in the CO treatments and soils treated with AS and VI. However, significant difference was not observed between them $(\mathrm{P}>0.05)$.

A good fit was observed between the FOK model and the remaining quantities of both pesticides as a function of time, and the values for the determination coefficients $\left(\mathrm{R}^{2}\right)$ varied in the range 0.63-0.99 (Table 3). Estimates of the $\mathrm{DT}_{50}$ values

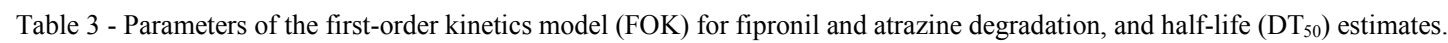

\begin{tabular}{|c|c|c|c|c|c|c|}
\hline Pesticides & Soils & Treatments & $\mathrm{C}_{0}(\%)$ & $k\left(\right.$ day $\left.^{-1}\right)$ & $\mathrm{R}^{2}$ & $\mathrm{DT}_{50}$ (days) \\
\hline \multirow{12}{*}{ Fipronil } & \multirow{6}{*}{ LVdf } & Sterile soil & $105.0 \pm 2.7^{*}$ & $0.009 \pm 0.001$ & 0.76 & $79(62-100)^{* *}$ \\
\hline & & Control & $97.6 \pm 2.9$ & $0.034 \pm 0.002$ & 0.95 & $20(18-23)$ \\
\hline & & Filter cake & $104.8 \pm 2.2$ & $0.013 \pm 0.001$ & 0.90 & $55(46-64)$ \\
\hline & & Straw & $103.5 \pm 2.8$ & $0.032 \pm 0.002$ & 0.96 & $22(19-25)$ \\
\hline & & Boiler ash & $98.5 \pm 2.9$ & $0.036 \pm 0.002$ & 0.95 & $19(17-22)$ \\
\hline & & Vinasse & $105.0 \pm 4.0$ & $0.046 \pm 0.003$ & 0.94 & $15(13-17)$ \\
\hline & \multirow{6}{*}{$\mathrm{LVd}$} & Sterile soil & $103.8 \pm 2.4$ & $0.007 \pm 0.001$ & 0.63 & $105(76-141)$ \\
\hline & & Control & $98.2 \pm 2.7$ & $0.023 \pm 0.002$ & 0.93 & $30(25-37)$ \\
\hline & & Filter cake & $100.9 \pm 2.5$ & $0.009 \pm 0.001$ & 0.78 & $77(62-100)$ \\
\hline & & Straw & $101.1 \pm 2.0$ & $0.022 \pm 0.001$ & 0.96 & $33(29-35)$ \\
\hline & & Boiler ash & $98.9 \pm 3.1$ & $0.027 \pm 0.002$ & 0.92 & $26(22-30)$ \\
\hline & & Vinasse & $104.9 \pm 3.9$ & $0.032 \pm 0.002$ & 0.91 & $22(19-25)$ \\
\hline \multirow{13}{*}{ Atrazine } & \multirow{6}{*}{ LVdf } & Sterile soil & $98.2 \pm 2.5$ & $0.041 \pm 0.002$ & 0.97 & $17(15-19)$ \\
\hline & & Control & $99.5 \pm 2.1$ & $0.047 \pm 0.002$ & 0.98 & $15(14-16)$ \\
\hline & & Filter cake & $99.7 \pm 1.3$ & $0.041 \pm 0.001$ & 0.99 & $17(16-18)$ \\
\hline & & Straw & $102.3 \pm 3.3$ & $0.089 \pm 0.005$ & 0.97 & $8(7-9)$ \\
\hline & & Boiler ash & $96.4 \pm 2.7$ & $0.054 \pm 0.003$ & 0.97 & $13(11-15)$ \\
\hline & & Vinasse & $103.6 \pm 3.8$ & $0.090 \pm 0.006$ & 0.97 & $8(7-9)$ \\
\hline & & & & & & \\
\hline & \multirow{6}{*}{ LVd } & Sterile soil & $97.1 \pm 1.9$ & $0.042 \pm 0.002$ & 0.98 & $17(15-18)$ \\
\hline & & Control & $98.6 \pm 2.2$ & $0.071 \pm 0.003$ & 0.99 & $10(9-11)$ \\
\hline & & Filter cake & $99.2 \pm 1.0$ & $0.047 \pm 0.001$ & 0.99 & $15(14-15)$ \\
\hline & & Straw & $98.5 \pm 2.9$ & $0.071 \pm 0.004$ & 0.97 & $10(9-11)$ \\
\hline & & Boiler ash & $99.1 \pm 3.8$ & $0.087 \pm 0.006$ & 0.96 & $8(7-9)$ \\
\hline & & Vinasse & $104.6 \pm 5.2$ & $0.096 \pm 0.009$ & 0.95 & $7(6-9)$ \\
\hline
\end{tabular}

${ }^{*}$ Mean \pm standard error. LVdf = Distroferric Red Latossol (typical of clay texture); LVd = Dystrophic Red Latossol (typical of medium texture). ${ }^{* *}$ Figures in parentheses represent the $95 \%$ confidence interval. 
for fipronil ranged from 15 to 105 days. All $\mathrm{DT}_{50}$ values for fipronil in the LVdf soil were lower than in the LVd soil. This indicates a faster degradation of this pesticide in the LVdf soil as compared to that in the LVd soil. After addition of VI to both soils, the $\mathrm{DT}_{50}$ values for fipronil were in general $25 \%$ lower as compared to the $\mathrm{CO}$ treatment (Table 3). The most rapid degradation of pesticides after soil treatment with VI was also observed by PRATA et al. (2001) and LOURENCETTI et al. (2012). Some studies reported that treatment with VI modifies temporarily some chemical and biological properties of the soil, increasing its fertility and organic matter content (CANELLAS et al., 2003), exchangeable acidity, and microbial biomass (MINHONI \& CERRI, 1987), which interfere directly with the pesticide behavior in the soil. In both soil types, the highest $\mathrm{DT}_{50}$ values for fipronil were reported in the ST soil and soils treated with FC (Table 3). Soil treatment with FC decreased the degradation rate of fipronil, making it more persistent. In general, the $\mathrm{DT}_{50}$ values for this pesticide were 2.5-fold higher than those obtained in soils not treated with this residue.

The $\mathrm{DT}_{50}$ values for atrazine varied in 7-17 days, suggesting that this pesticide has a low persistence in the studied soils. In addition, the $\mathrm{DT}_{50}$ values for atrazine in the $\mathrm{CO}$ treatments and ST soil were similar (Table 3). This indicated that the microbial degradation process under the conditions studied was not the major pathway for atrazine degradation, suggesting a mainly chemical degradation. Atrazine is a triazine-class herbicide, and chemical hydrolysis is the major route of its degradation in the soil, being a relatively fast process in acidic or basic soils and slow in neutral soils (LEBARON, 2008). The hypothesis of chemical degradation proposed in this study is based on the observation that the studied soils are acidic ( $\mathrm{pH}$ range 4.8-4.9). The smallest $\mathrm{DT}_{50}$ values for atrazine were observed in both soils treated with SR, AS, and VI (Table 3). In presence of these residues, a decrease was observed in the $\mathrm{DT}_{50}$ values for atrazine in the LVdf (up to $46 \%$ ) and LVd (30\%) soils.

Regarding fipronil sorption, a significant interaction $(p<0.05)$ was observed between soil types and organic residues (Table 4). The Kd values for fipronil varied in the range $5.1-13.2 \mathrm{~mL} \mathrm{~g}^{-1}$. Significant difference was not observed $(\mathrm{P}>0.05)$ between the $\mathrm{Kd}$ values, where residues were added to the $\mathrm{LVd}$ soil. However, a significant difference $(\mathrm{P}<0.05)$ was observed between the $\mathrm{Kd}$ values after addition of $\mathrm{SR}$
Table 4 - Sorption coefficients $\left(\mathrm{Kd} ; \mathrm{mL} \mathrm{g}^{-1}\right)$ for fipronil and atrazine.

\begin{tabular}{|c|c|c|c|c|}
\hline \multirow{2}{*}{ Pesticides } & \multirow{2}{*}{ Treatments } & \multicolumn{2}{|c|}{----------Soils----------- } & \multirow{2}{*}{ Means } \\
\hline & & LVdf & LVd & \\
\hline \multirow{5}{*}{ Fipronil } & Straw & $13.2 \mathrm{aA}$ & 8.6 a B & 10.9 \\
\hline & Filter cake & $12.2 \mathrm{aA}$ & $7.0 \mathrm{a} \mathrm{B}$ & 9.6 \\
\hline & Control & 9.9abA & $5.1 \mathrm{a} \mathrm{B}$ & 7.5 \\
\hline & Boiler ash & $8.5 \mathrm{bA}$ & 5.8 a B & 7.2 \\
\hline & Vinasse & $6.9 \mathrm{bA}$ & 6.5 a B & 6.7 \\
\hline \multirow[t]{2}{*}{ Means } & & 10.1 & 6.6 & 8.4 \\
\hline & Straw & 1.5 & 1.4 & $1.4 \mathrm{a}$ \\
\hline \multirow{4}{*}{ Atrazine } & Filter cake & 1.1 & 0.9 & $1.0 \mathrm{~b}$ \\
\hline & Control & 0.7 & 0.5 & $0.6 \mathrm{c}$ \\
\hline & Boiler ash & 1.4 & 1.4 & $1.4 \mathrm{a}$ \\
\hline & Vinasse & 0.9 & 1.0 & $1.0 \mathrm{~b}$ \\
\hline Means & & $1.1 \mathrm{~A}$ & $1.0 \mathrm{~A}$ & 1.1 \\
\hline
\end{tabular}

$\mathrm{CV}$ fipronil $=16.4 \% ; \mathrm{CV}$ atrazine $=12.4 \% ;$ Mean values followed by the same letter (lower case in the column and upper case in the row) for each individual pesticide are not significantly different by the Tukey's test $(5 \%)$.

and FC to the LVdf soil (Table 4). Conversely, addition of AS and VI to the LVdf soil caused a significant decrease $(\mathrm{P}<0.05)$ in the $\mathrm{Kd}$ values, as compared to addition of SR and FC. The residues SR and FC have the highest organic carbon content and a high cation exchange capacity (Table 1 ). These properties probably caused the highest fipronil sorption by soil treated with SR and FC.

\section{CONCLUSION}

Fipronil and atrazine degradation was accelerated in soils with vinasse; whereas, fipronil degradation was decreased in both soils with filter cake. The half-life values for fipronil (15-105 days) and atrazine (8-17 days) varied, indicating that these pesticides have a low persistence in the soil. In general, addition of straw, filter cake, boiler ash, and vinasse to the soil increased atrazine sorption.

\section{REFERENCES}

ALCARDE, J.C. Métodos-padrão, detalhes analíticos e cálculos. In: NEVEN, E.M. Manual de análise de fertilizantes. Piracicaba: FEALQ, 2009. p.41-170.

CANELLAS, L.P. et al. Chemical soil properties of an inceptisol under long-term sugarcane crops with vinasse application and without slash burning. Revista Brasileira Ciência do Solo, v.27, n.5, p.935-944, 2003. Available from: <http:/www.scielo.br/scielo. php? script $=$ sci_abstract\&pid $=$ S0100-06832003000500018\& lng $=$ en\&nrm=iso\&tlng=pt>. Accessed: May 15, 2015. doi: 10.1590/ S0100-06832003000500018. 
CONAB (COMPANHIA NACIONAL DE ABASTECIMENTO). Brasília: Ministério da Agricultura, Pecuária e Abastecimento, 2014. Available from: <http://www.conab.gov.br/conteudos. php $? \mathrm{a}=1252 \& \mathrm{t}=\&$ Pagina_objcmsconteudos $=2 \#$ A objcmsconteudos>. Accessed: Apr. 2, 2015.

GIORI, F.G. et al. Sugarcane straw management and soil attributes on alachlor and diuron sorption in highly weathered tropical soils. Journal of Environmental Science and Health, Part B, v.49, p.352-360, 2014a. Available from: <http://www.tandfonline.com/ doi/abs/10.1080/03601234.2014.882172? journalCode=lesb20 $>$. Accessed: May 15, 2015. doi: 10.1080/03601234.2014.882172.

GIORI, F.G. et al. The role of sugarcane residues in the sorption and leaching of herbicides in two tropical soils. Water, Air, \& Soil Pollution, v.225, n.4, p.1-9, 2014b. Available from: <http://link. springer.com/article/10.1007\%2Fs11270-014-1935-8>. Accessed: May 15, 2015. doi: 10.1007/s11270-014-1935-8.

JIANG, Z.P. et al. Effect of long-term vinasse application on physico-chemical properties of sugarcane field soils. Sugar Tech, v.14, n.4, p.412-417, 2012. Available from: <http://link.springer com/article/10.1007\%2Fs12355-012-0174-9>. Accessed: May 15, 2015. doi: 10.1007/s12355-012-0174-9.

LEBARON, H.M. et al. The triazine herbicides 50 years revolutionizing agriculture. San Diego: Elsevier, 2008. 584p.

LOURENCETTI, C. et al. Influence of sugar cane vinasse on the sorption and degradation of herbicides in soil under controlled conditions. Journal of Environmental Science and Health, Part B, v.47, p.949-958, 2012. Available from: $<$ http://www.tandfonline.com/doi/abs/10.1080/03601234.2012 .706562 ?journalCode $=$ lesb20 $>$. Accessed: May 15, 2015. doi: $10.1080 / 03601234.2012 .706562$.

MINHONI, M.T.A.; CERRI, C.C. Degradation of vinasse in soil under different humidity levels: $\mathrm{CO}_{2}$ liberation, microbial biomass formation and immobilization of added nitrogen. Revista Brasileira de Ciência do Solo, v.11, p.25-30, 1987.

OECD (ORGANIZATION FOR ECONOMIC AND COOPERATION AND DEVELOPMENT). OECD guideline for testing of chemicals 106. Adsorption-desorption using a batch equilibrium method. 2000. 45p. Available from: $<$ http://www.oecd- ilibrary.org/environment/test-no-106-adsorption-desorption-usinga-batch-equilibrium-method 9789264069602-en>. Accessed: May 15, 2015. doi: 10.1787/20745753.

OECD (ORGANIZATION FOR ECONOMIC AND COOPERATION AND DEVELOPMENT). OECD guideline for testing of chemicals 307. Aerobic and anaerobic transformation in soil. 2002.17p. Available from: <http://www.oecd-ilibrary.org/ environment/test-no-307-aerobic-and-anaerobic-transformationin-soil_9789264070509-en>. Accessed: Oct. 05, 2015. doi: $10.1787 / 9789264070509$-en.

PEREIRA-JUNIOR, E.V. et al. Effects of soil atributes and straw accumulation on the Sorption of hexazinone and tebuthiuron in tropical soils cultivated with sugarcane. Journal of Environmental Science and Health, Part B, v.50, p.238-246, 2015. Available from: <http://www.tandfonline.com/doi/full/10 .1080/03601234.2015.999588>. Accessed: May 15, 2015. doi: $10.1080 / 03601234.2015 .999588$

PIATV. Programa interlaboratorial de análise de tecido vegetal. Available from: <http://www.piatv.com.br/>. Accessed: Apr. 29, 2014.

PRATA, F. et al. Degradation and sorption of ametryne in two soils with vinasse application. Pesquisa Agropecuária Brasileira, v.36, n.7, p.975-981, 2001. Available from: <http://www.scielo. br/scielo.php?pid=S0100-204X2001000700007\&script $=$ sci arttext>. Accessed: May 15, 2015. doi: 10.1590/S0100$204 X 2001000700007$.

R DEVELOPMENT CORE TEAM. R: a language and environment for statistical computing. Vienna: R Foundation for Statistical Computing, 2012. Available from: <https://www.r-project.org/>. Accessed: May 15, 2015.

SANTOS, H.G. et al. Sistema brasileiro de classificação de solos. 2.ed. Rio de Janeiro: Embrapa Solos, 2006. 306p.

VASCONCELOS, R.F.B. et al. Limits of consistency chemical properties of a dystrophic cohesive yellow latosol under different sugarcane residues. Revista Brasileira de Ciência do Solo, v.34, n.3, p.639-648, 2010. Available from: $<$ http://www.scielo.br/scielo. php? script $=$ sci_abstract\&pid $=$ S0100-06832010000300005\&lng $=\mathrm{em} \& \mathrm{nrm}=\mathrm{iso} \& \mathrm{t} \operatorname{lng}=\mathrm{pt}>$. Accessed: May 15, 2015.doi: 10.1590/ S0100-06832010000300005. 